\title{
Sosiale motiewe en stereotipering in verbruikers se keuse van groot elektriese toerusting
}

\author{
Suné Donoghue en Alet C Erasmus
}

\begin{abstract}
This was an exploratory and descriptive study of the role of social motives and consumer stereotyping in selected upcoming consumers' choice of large electrical household appliances. Symbolic interactionism served as a perspective to the study, combined with a cognitive approach. A qualitative research strategy was followed using unstructured interviews and projective techniques as datacollecting techniques.
\end{abstract}

The sample consisted of two black, upcoming, female subjects from a higher-middle- income group. Both had first-hand experience with electricity in their homes.

The results of this study indicated that family and friends, as significant others, influenced the subjects' choice of large electrical household appliances. The subjects learned the perspectives of their aspiration reference groups (people from the higher socioeconomic groups) through symbolic interaction. These perspectives directed their acquisition of large electrical household appliances. They apparantly formed stereotypes of members of the higher socioeconomic groups and allocated certain symbolic meanings to them, based on visual, conspicuous characteristics such as their ownership of large electrical household appliances.

Social motives seemed to guide the subjects' choice of large electrical household appliances. The subjects seemed to be under the impression that their large electrical household appliances - beyond having a definite functional purpose - portrayed symbolic meaning about themselves.

\section{- Me S Donoghue}

\section{- Mev AC Erasmus}

Departement Huishoudkunde, Universiteit van Pretoria

\section{AGTERGROND}

Die keuse van groot elektriese huishoudelike toerusting word deur ' $n$ aantal eksterne faktore soos die prys, funksionele werkverrigting en duursaamheid beïnvloed. Elektriese huishoudelike toerusting kan egter ook met ander oogmerke aangekoop word, byvoorbeeld om ' $n$ bepaalde boodskap uit te dra.

\begin{abstract}
Verskeie kwantitatiewe navorsingstudies is al in die verlede gedoen om meer lig te werp op verbruikers se eienaarskap en prioriteite met betrekking tot die keuse en aankoop van elektriese huishoudelike toerusting (Markinor Omni Panel Survey, 1997; Erasmus, 1997). Daar kon egter nie inligting oor verbruikers se onderliggende redes (motiewe) vir die keuse van elektriese huishoudelike toerusting gevind word nie. In die kwantitatiewe studies wat wel opgespoor is, is hoofsaaklik op kwantitatiewe metodes met die oog op universele stellings gefokus en sodanige metodes beskik selde oor die metodiek om die mens/verbruiker te verstaan of om vas te stel hoe die mens/verbruiker sy wêreld beleef.
\end{abstract}

\begin{abstract}
Heelwat literatuur is beskikbaar oor motiveringsnavorsingstudies oor die psigoanalitiese en kliniese aspekte van die sielkunde (Engel et al, 1995:418). Verskeie navorsingstudies is al op die gebied van die sosiaal-sielkunde en ook die sosiaal-sielkundige aspekte van kleding met betrekking tot stereotipering gedoen (Hamilton, 1979; Darley \& Gross in Fiske \& Taylor, 1984:100; Clayson \& Maughan, Dion et al, en Litman et al in Lennon \& Davis, 1989). Daar is egter 'n leemte met betrekking tot literatuur op die gebied van verbruikerstereotipering en die rol van sosiale motiewe by die verbruiker se keuse van groot elektriese huishoudelike toerusting.
\end{abstract}

In die lig van die bogenoemde is besluit om 'n kwalitatiewe benadering te volg om ondersoek in te stel na die rol van sosiale motiewe en verbruikerstereotipering by swart, vroulike, opkomende verbruikers - spesifiek wat hulle keuse van groot elektriese huishoudelike toerusting betref.

\section{TEORETIESE RAAMWERKE}

Die kwalitatiewe navorser is daarop ingestel om die versteekte of onderliggende motiewe van gedrag, binne 'n sekere konteks eerder as 'n universele verband, te verstaan, te verken en te beskryf (in teenstelling met 'n verklaring daarvan) (De Klerk, 1993; Mouton, 1983; Mouton \& Marais, 1990:159). 
Wanneer die simboliese interaksionisme as perspektief in die kwalitatiewe benadering tot ' $n$ studie gebruik word, word gefokus op die subjektiewe bedoelinge en ingesteldhede van individue - hul begeertes, wense en motiewe, hoe hulle betekenis aan simbole heg, en hul oriëntasie tot of definisie van situasies (Bogdan \& Taylor, 1975:14-16; Van Rensburg \& De Klerk, 1984). Wanneer 'n kognitiewe benadering wat met die simboliese interaksionisme versoenbaar is daarby betrek word, kan die kognitiewe prosesse asook die interaksieproses en interpretasie van die boodskap bestudeer word (Kaiser, 1983-1984; Nagasawa et al, 1991).

\section{Die simboliese interaksionisme}

Charon (1979:24) noem dat die simboliese interaksionisme dit duidelik as 'n onderliggende aanname stel dat die mens as aktiewe en dinamiese wese gedurig in interaksie met ander is. "Ander" en "interaksie" is twee sentrale begrippe in die simboliese interaksionisme. Ander verwys na die betekenisvolle ander, veralgemeende ander en verwysingsgroepander (Van Rensburg \& De Klerk, 1984). "Betekenisvolle ander" dui op persone wat vir die self belangrik is, vir wie hy graag wil beïndruk, met wie hy identifiseer en wat ' $n$ aansienlike invloed op hom uitoefen (Van Rensburg \& De Klerk, 1984; Charon, 1979:66). Die persoon neem die rol van "veralgemeende ander" aan, wanneer hy sinvol moet reageer op die houdings en verwagtinge wat algemeen vir die gemeenskap geld. "Verwysingsgroepander" is groepe waaraan die individu graag sou wou behoort of met wie hy identifiseer (Charon, 1979:26).

"Interaksie" word beskou as simboliese interaksie, dat 'n mens deur middel van 'n simbool (hetsy taal of die interpretasie van sosiale objekte as simbole) verbaal of nieverbaal met ander kommunikeer, die kommunikasiesimbool interpreteer, betekenis daaraan heg en dit sodoende as medium gebruik om boodskappe te stuur en te onvang (Charon, 1979:35-43; Van Rensburg \& De Klerk, 1984; Kaiser, 1990:41).

Die voorgaande lei tot 'n tweede basiese aanname, naamlik dat die mens ' $n$ simboliese wese is en objekte in sy omgewing gebruik en interpreteer om sin uit 'n bepaalde interaksiesituasie te maak. Dit benadruk die belangrikheid van 'n "simbool" binne die simboliese interaksionisme, naamlik dat ' $n$ mens ' $n$ fisiese objek as ' $n$ sosiale objek kan gebruik, maar ook verdere betekenis daaraan kan heg (Charon, 1979:35-43).

Met betrekking tot hierdie studie impliseer bogenoemde dat die verbruiker elektriese huishoudelike toerusting (as 'n fisiese objek met funksionele werkverrigtingswaarde) as 'n sosiale objek gebruik wanneer betekenis daaraan geheg word en dit 'n simboliese betekenis verkry.

'n Derde en vierde aanname stel dat dit tydens interaksie nie net gaan oor wat tussen mense gebeur nie, maar ook oor wat in die individu self gebeur, hoe hy ' $n$ situasie vir homself definieer. Charon (1979:136) meen dat ander tydens interaksie in 'n bepaalde situasie gedefinieer of ge-etiketteer word. Die etikette wat rondom ander gehang word, definieer wie hulle is en bepaal ' $n$ mens se optrede teenoor hulle. Omdat die mens aktief by interaksie met ander betrokke is, is dit vir hom moontlik om homself te rig deur die perspektiewe aan te neem van die ander met wie hy in interaksie verkeer (Charon, 1979:24).

Met betrekking tot hierdie studie impliseer dit dat die verbruiker die perspektiewe van ander deur simboliese interaksie aanleer. Saam met ander speel dit 'n belangrike rol in die gebruik van sosiale objekte as simbole om sin uit 'n bepaalde interaksiesituasie te maak en op 'n bepaalde gedragswyse te besluit. Alvorens die verbruiker besluit om elektriese huishoudelike toerusting te koop, mag hy oorweeg wat ander onder dieselfde omstandighede as hy sou doen, of wat hulle van hom sou dink indien hy 'n bepaalde gedrags-lyn sou volg.

\section{'n Kognitiewe benadering}

Nagasawa en medewerkers (1991) stel in die aannames vir ' $n$ kognitiewe benadering dat die mens ' $n$ rasioneel denkende wese is wat sin uit die sosiale wêreld wil maak. Mense prosesseer eksterne stimuli deur middel van interne meganismes (kognitiewe strukture) wat inligting ontvang en organiseer. Hierdie kognitiewe strukture dien ook as agtergrond waarteen mense die wêreld en diegene met wie hulle in interaksie verkeer verstaan en hulle sosiale realiteit konstrueer. Dit bied dus ' $n$ mate van orde en voorspelbaarheid met die doel om verwagtinge te verklaar en ander se gedrag te verduidelik (Kaiser, 1990:252).

"Kategorisering" en "stereotipering" is twee begrippe uit 'n kognitiewe benadering wat by hierdie studie betrek is. Volgens Kaiser (1990:254) en Hamilton (1979) is mense geneig om ander in sosiale groepe te kategoriseer. Dit is ' $n$ essensiële komponent van stereotipering (Allport in Hamilton, 1979; Lennon \& Davis, 1989; Kaiser, 1990:155). Stereotipering geskied wanneer kognitiewe kortpaaie gebruik word om slegs die mees beskikbare, ooreenstemmende en opvallende inligting tydens beoordeling te selekteer en te kategoriseer (Allport in Hyatt, 1992:301). Die be-grip "stereotipe" verwys na die waarnemer se verwagtinge oor die lede van 'n sosiale groep (Hamilton, 1979; Hyatt, 1992:301). Verwagtinge oor 'n sosiale groep en hul besittings/aankoopgedrag kan dus as stereotipes gebruik word om persoonlike gedrag/aankope te rig.

\section{DOEL MET DIE NAVORSING}

Om die probleem wat vir die studie gestel is te ondersoek, is die volgende vrae/subdoelwitte met betrekking tot die deelnemers (twee swart vroulike verbruikers) aan die studie geformuleer:

- Watter rol speel sosiale motiewe tydens hulle interaksie met ander om hulle keuse van groot elektriese huishoudelike toerusting te rig? 
- Gebruik hulle ander se eienaarskap van groot elektriese huishoudelike toerusting as ' $n$ simbool om stereotipiese afleidings/veralgemenings omtrent die eienaars van die toerusting te maak?

- Dien hulle keuse van groot elektriese huishoudelike toerusting as ' $n$ simbool om betekenisse aan ander met wie hulle in interaksie verkeer te kommunikeer?

\section{NAVORSINGSONTWERP}

\section{Keuse van 'n navorsingstrategie en -doel}

'n Idiografiese/kontekstuele navorsingstrategie is as uitgangspunt gevolg. Die domeinverskynsel is dus aan die hand van die onmiddellike konteks bestudeer eerder as om die bevindinge van die studie te veralgemeen (Mouton \& Marais, 1990:51-53).

' $n$ Verkennend beskrywende benadering is gevolg. ' $n$ Verkennende benadering lei tot insig en begrip en behels onder andere ' $n$ oorsig van die bestaande toepaslike literatuur en 'n opname onder mense wat praktiese ervaring van die probleem het (Mouton \& Marais, 1990:45). Die beskrywende benadering impliseer dat die navorser ten doel het om "dit wat is" op die een of ander wyse akkuraat te beskryf (Mouton \& Marais, 1990:46).

\section{Seleksie van subjekte}

Ses swart volwasse vroulike verbruikers is op 'n gerieflikheidsbasis as potensiële deelnemers aan die studie geïdentifiseer. Almal was bereid om aan die studie deel te neem en het toestemming van hulle werkgewers gehad om gedurende werktyd na winkelsentrums geneem te word. Die volgende seleksiekriteria het vir die subjekte gegeld:

- Hulle moes aan die hoëmiddel- tot hoëinkomstegroep behoort ('n bruto maandelikse salaris van R3 000) sodat hulle die aankoop van elektriese huishoudelike toerusting in die vooruitsig kon stel.

- Hulle ouderdom moes tussen 25 en 50 jaar wees. Gegewe die fases van die lewensiklus van 'n gesin word ' $n$ persoon wat in hierdie ouderdomsgroep val beskou as iemand wat in die gebruik van elektriese huishoudelike toerusting belangstel en oor die potensiaal beskik om sodanige toerusting aan te koop.

- Hulle moes elektrisiteit in hulle huise hê om te verseker dat hulle uit ondervinding in staat sou wees om reeds gevormde persepsies oor elektriese huishoudelike toerusting uit te spreek (Erasmus, 1997).

\section{Keuse van data-insamelingstegnieke}

Ongestruktureerde onderhoude is aan die hand van 'n skedule gebruik. Temas uit die bestaande literatuur is geïdentifiseer en as ' $n$ riglyn vir die onderhoude gebruik om relevante onderwerpe vir die studie op 'n sistematiese wyse te dek (Schurink, 1988:139). Vrae is formuleer. Hoewel die subjekte aangemoedig is om vrylik te gesels, is hulle waar nodig met dieptepeiling (polsing) gestimuleer om bykomende inligting oor ' $n$ onderwerp te verstrek.

Projektiewe data-insamelingstegnieke is ingesluit om aan die subjekte die geleentheid te bied om op dubbelsinnige of ongestruktureerde stimuli, situasies of materiaal te reageer. Die subjekte kon so hulle persoonlikhede, houdings, opinies en selfkonsep as ' $n$ integrale deel van die self projekteer om struktuur/betekenis aan 'n situasie te gee (Adams \& Schvaneveldt in Burns \& Lennon, 1993; Morgan \& King, 1975:242; Kassarjian in Ferber, 1974:3-86). Volgens Hawkins et al (1992:647), Haire (1950) en Loudon en Della Bitta (1993:300) kan 'n individu se interpretasie van dubbelsinnige stimuli beskou word as ' $n$ weerspieëling van sy eie houdings, waardes en motiewe omdat dubbelsinnige stimuli juis op verskeie wyses geïnterpreteer kan word en omdat daar geen regte of verkeerde antwoorde ten opsigte van die bepaalde projektiewe tegniek bestaan nie (Kassarjian in Ferber, 1974:3-86).

Die sinsvoltooiingstegniek en bepaalde konstruksietegnieke is in hierdie studie as projektiewe tegnieke gebruik. Volgens Gordon en Langmaid (1988:98) en Burns en Lennon (1993) lok die sinsvoltooiingstegniek direkte reaksie by subjekte uit, dus die reaksie wat net onder die oppervlak lê. Konstruksietegnieke vereis daarenteen meer komplekse kognitiewe aktiwiteit van die subjek (Gordon \& Langmaid, 1988:103-106). In hierdie studie is die volgende konstruksietegnieke gebruik:

- Subjekte is gevra om te reageer op een of meer prentjies wat met die onderwerp van bespreking verband hou, deur telkens die rol van die persoon in die prentjie aan te neem en sekere aspekte wat in die situasie uitgebeeld word te beskryf. Die subjek moes sê wat het gebeur, wat in die toekoms gaan gebeur, en 'n karakterbeskrywing van die persoon, vanuit 'n ander persoon se oogpunt, voorsien.

- Die subjek is na ' $n$ afdelingswinkel geneem waar sy na blootstelling aan bepaalde elektriese huishoudelike toerusting (as stimuli) moes reageer deur 'n keuse uit te oefen. Dit is hipoteties aan die subjek gestel dat die groot elektriese huishoudelike kombuistoerusting wat sy besit, gesteel is, dat die versekeringsmaatskappy by wie die inhoud van haar huis verseker is 'n bedrag van R7 000 aan haar uitbetaal het, en dat sy die geleentheid het om nuwe, groot elektriese huishoudelike toerusting te koop. Die subjek is meegedeel dat sy by benadering R7 000 kon uitgee. Die navorser wou bepaal hoe die respondent haar keuse ten opsigte van die wye spektrum groot elektriese huishoudelike toerusting van verskillende prysklasse maak. Die subjekte is dus aan 'n relatief ongestruktureerde situasie blootgestel waar hulle hul opinies moes projekteer om struktuur daaraan te voorsien.

\section{Verloop van die studie}


Tydens die eerste kontakgeleentheid is individuele, informele gesprekke gevoer met ses persone wat aan al die vereistes vir deelname aan die studie voldoen het. ' $n$ Konstruksietegniek is gebruik om subjekte vir die verdere verloop van die navorsingstudie te identifiseer. Twee persone wat tydens hulle eerste ontmoeting ongeïnhibeerd deelgeneem het en oor goeie kommunikasievaardighede beskik, is geselekteer.

Tydens die tweede kontakgeleentheid is onderhoude gevoer om demografiese inligting en inligting in te win oor die elektriese huishoudelike toerusting wat die subjekte besit. Die subjekte is na afloop van die onderhoude na ' $n$ afdelingswinkel geneem en aan ' $n$ konstruksietegniek blootgestel. Hierna het 'n onderhoud met elkeen by haar werkgewer gevolg om haar reaksie op die projektiewe tegniek te verkry.

Tydens die derde, vierde en vyfde kontakgeleenthede is 'n ongestruktureerd onderhoude met elke subjek gevoer om inligting omtrent haar sosiale motiewe en verbruikerstereotipering te verkry. Tydens die laaste twee kontakgeleenthede is projektiewe tegnieke (sinsvoltooiingstegnieke en konstruksietegnieke) toegepas om inligting in te win.

\section{VASLEGGING EN VERWERKING VAN DATA}

\section{Datavaslegging}

Die navorser het notas geneem van die informele onderhoude tydens die eerste en tweede kontakgeleenthede. Die gebruik van ' $n$ bandopnemer is vermy omdat dit die subjekte ongemaklik kon laat voel. Op daardie stadium was die navorser nog relatief onbekend aan hulle en geen vertrouensverhouding was nog gevestig nie. Die gebruik van 'n bandopnemer tydens die winkelbesoek sou ook onprakties wees en onnodig aandag trek.

Die onderhoude wat tydens die derde, vierde en vyfde kontakgeleenthede plaasgevind het, is wel op band vasgelê. Die bandopnames is na afloop van die onderhoude getranskribeer en parafrases is van die onderhoude geskryf. Die subjekte se beskrywings/ stories en verduidelikings van die konstruksietegnieke wat op band vasgelê is, is op skrif gestel vir dataanalise. Die parafrases en response op die konstruksietegnieke is direk geskryf soos die subjekte dit weergegee het.

\section{Data-analise en -verwerking}

Die volgende stappe is vir die ontleding van die data gevolg:

- Die literatuur is as riglyn gebruik om navorsingsvrae/subdoelwitte te formuleer en om kategorieë of temas te identifiseer.

- Die data is volgens die gestelde kategorieë of temas georden en met behulp van die toepaslike wetenskaplike teorieë vir die simboliese interak- sionisme, 'n kognitiewe benadering en verbruikersgedrag geïnterpreteer en beskryf.

- Hipoteses is gegeneer en 'n konseptuele raamwerk is ontwikkel.

Tweedeorde temas vir data-analise is ooreenkomstig die navorsingsvrae gekategoriseer. Die response van die subjekte - waaruit die eersteordekonsepte onttrek is -is daaronder gesorteer. Die kategorieë word in die volgende paragrawe bespreek.

Die rol van sosiale motiewe tydens twee opkomende verbruikers se interaksie met ander om hulle keuse van groot elektriese huishoudelike toerusting te rig

Sosiale motiewe manifesteer in die verbruiker se behoefte aan selfuitdrukking, egobeskerming, selfgelding, affiliasie, modellering en versterking (McGuire in Hawkins et al, 1992:300-303):

- Verbruikers se behoefte aan selfuitdrukking blyk uit verwysings wat daarop dui dat hulle ' $n$ behoefte het om hulle identiteit aan ander uit te wys (McGuire in Hawkins et al, 1992:300).

- Verbruikers se behoefte aan egobeskerming kom tot uiting in verwysings wat daarop dui dat hulle hulself wil beskerm teen 'n sosiale verleentheid en ander bedreigings wat hulle gevoel van selfagting kan verlaag (McGuire in Hawkins et al, 1992:302).

- Verbruikers se behoefte aan selfgelding word weerspieël in verwysings na ' $n$ behoefte om deel te neem aan aktiwiteite wat agting vir hulself en deur ander persone kan verhoog (McGuire in Hawkins et al, 1992:302)

- Verbruikers se behoefte aan affiliasie manifesteer in verwysings wat dui op 'n behoefte aan wedersydse verhoudings met ander persone en om deur ander aanvaar te word (McGuire in Hawkins et al, 1992:302-303).

- Verbruikers se behoefte aan modellering blyk uit enige respons/verwysing wat dui op 'n geneigdheid om die gedrag na te boots van persone met wie hulle identifiseer (McGuire in Hawkins et al, 1992:303).

- Verbruikers se behoefte aan versterking kom tot uiting in verwysings wat impliseer dat dieselfde visueel opvallende produkte (byvoorbeeld huishoudelike toerusting) herhaaldelik gekoop sal word vanweë die positiewe reaksie wat dit tot gevolg het (McGuire in Hawkins et al, 1992:302).

Twee opkomende verbruikers se gebruik van ander persone se eienaarskap van groot elektriese huishoudelike toerusting as 'n simbool om stereotipiese afleidings/veralgemenings oor die persone te maak

- Die ander persone met wie die opkomende verbruiker in interaksie verkeer dui op die betekenisvolle ander, veralgemeende ander en verwysingsgroep-ander.

- Ander persone se eienaarskap van groot elektriese huishoudelike toerusting as 'n simbool dui op 
die simboliese betekenisse wat die toerusting uit die opkomende verbruiker se oogpunt oor die eienaars van die toerusting kommunikeer.

- Stereotipiese afleidings/veralgemenings oor ander dui op die opkomende verbruiker se assosiasie van die eienaarskap van elektriese huishoudelike toerusting met die lede van bepaalde sosiale kategorieë.

Twee opkomende verbruikers se keuse van groot elektriese huishoudelike toerusting as 'n simbool om betekenisse aan ander met wie hulle in interaksie verkeer te kommunikeer

Dit sluit verwysings in wat impliseer dat die opkomende verbruiker haar eienaarskap/keuse van elektriese huishoudelike toerusting gebruik om betekenisse aan ander te kommunikeer.

\section{Geloofwaardigheid}

Die geloofwaardigheid van die studie berus op deeglike teoretiese definiëring (konseptualisering) na 'n omvattende literatuurstudie oor toepaslike teorieë rondom die geformuleerde navorsingsprobleme. Die literatuur is gebruik om temas (wat die tweedeordekonsepte gelewer het) te identifiseer waarvolgens die subjekte se reaksie en beskouings (die eersteordekonsepte) onttrek en beskryf is. Meerdere data-insamelingsmetodes is gebruik om die tersaaklike konstrukte te beskryf.

Mouton en Marais (1990:92) meen dat inligting wat deur kwalitatiewe navorsing ingewin word, meer betroubaar is wanneer intermetodiese kruisvalidasie of meerdere data-insamelingstegnieke toegepas word. In die lig hiervan is verskeie onderhoude gevoer en verskillende projektiewe tegnieke by verskillende kontakgeleenthede toegepas. Die subjekte in hierdie studie kon dus by verskeie geleenthede oor die navorsingsonderwerp gesels en projeksies maak.

Meerdere kontakgeleenthede het dit vir die navorser moontlik gemaak om die subjekte beter te leer ken en om 'n vertrouensverhouding met hulle op te bou. Die bandopnemer is nie gedurende die eerste twee kontakgeleenthede gebruik nie om ongemak wat die subjekte kon ervaar te verhoed. In 'n poging om ongeïnhibeerde deelname aan te moedig, is die subjekte van anonimiteit verseker met die gebruik van skuilname in die navorsingsverslag. Die invloed van kontekseffekte is uitgeskakel deur die kontakgeleenthede in die subjekte se werktye te reël. Die onderhoude is in ' $n$ bekende milieu by die onderskeie werkgewers in 'n privaat kantoor gevoer.

Die geloofwaardigheid van die inligting is verhoog deur subjekte te identifiseer wat oor goeie kommunikasievaardighede beskik en ongeïnhibeerd aan die proses kon deelneem. Subjekte is geselekteer wat elektrisiteit in hulle huise het en reeds groot elektriese huishoudelike toerusting besit en gebruik. Inligting is dus ingewin wat op persoonlike ervaring en eie persepsies berus en wat dus meer geloofwaardig is.
Die twee subjekte het mekaar nie geken nie en kon mekaar dus nie beïnvloed in die weergee van inligting nie.

Vanweë die kontekstuele strekking van die studie is die resultate nie vir die groter populasie van opkomende verbruikers veralgemeen nie.

\section{RESULTATE EN BESPREKING}

Die resultate word aangebied in ooreenstemming met die vrae/subdoelwitte wat vir die studie gestel is.

Die rol van sosiale motiewe tydens twee opkomende verbruikers se interaksie met ander om hul keuse van groot elektriese huishoudelike toerusting te rig

Uit die reaksie van die subjekte blyk dat bepaalde sosiale motiewe wel hulle keuse van groot elektriese huishoudelike toerusting beïnvloed (Kyk Tabel 1).

\section{Behoefte aan selfuitdrukking Volgens Hawkins} et al (1992:300) kan die verbruikers hulle identiteit aan ander openbaar deur die aankoop en vertoon van visueel opvallende produkte wat simboliese of ekspressiewe betekenisse het. In hierdie studie erken die subjekte dat hulle deur die koop en vertoon van bepaalde groot elektriese huishoudelike toerusting aan ander persone wys wie en wat hulle is - mense wat daarna strewe om ' $n$ hoë lewenspeil te handhaaf.

Behoefte aan egobeskerming Onseker verbruikers kan sekere visueel opvallende produkte (wat aanvaarbaar binne hulle bepaalde sosiale klas is) koop om te voorkom dat hulle 'n sosiaal verkeerde/ onaanvaarbare aankoop maak en so in die verleentheid gestel word (Hawkins et al, 1992:302). Die subjekte in hierdie studie erken dat hulle vriendinne en familie raadpleeg wanneer hulle onseker voel oor bepaalde elektriese huishoudelike toerusting, handelsname, en veiligheids- en duursaamheidsaspekte. Hulle maak dus staat op die ondervinding van hierdie mense en gebruik hulle as vertrouelinge - veral om hulle van verkeerde aankope te weerhou.

Behoefte aan selfgelding Die behoefte aan selfgelding kom tot uiting in verbruikers se strewe om aan ander te wys dat hulle suksesvol kan meeding (Loudon \& Della Bitta, 1993:328). Die subjekte in hierdie studie ervaar 'n gevoel van trots wanneer hulle groot elektriese huishoudelike toerusting koop aangesien hulle glo dat die meeste mense die toerusting sal waardeer. Hulle probeer juis om dieselfde elektriese huishoudelike toerusting te koop as die persone wat hulle admireer (die hoër sosioekonomiese klasse).

Behoefte aan affiliasie Groeplidmaatskap vorm ' $n$ belangrike deel van ' $n$ verbruiker se daaglikse omgang met ander (McGuire in Hawkins et al, 1992:303). In hierdie studie word die subjekte se aankoop van groot elektriese huishoudelike toerusting 
TABEL 1: $\quad$ STELLINGS WAT DUI OP DIE ROL VAN SOSIALE MOTIEWE TYDENS INTERAKSIE MET ANDER OM DIE KEUSE VAN GROOT ELEKTRIESE HUISHOUDELIKE TOERUSTING TE RIG

\begin{tabular}{|c|c|}
\hline Sosiale motiewe & Subjekte se stellings \\
\hline Behoefte aan selfuitdrukking & $\begin{array}{l}\text { Other people might think that I am just like the people of Hospital Hill and Hospital } \\
\text { View. I like modern things, I am advanced and like the people of today - I like new } \\
\text { things and changes. } \\
\text {... somehow they can see that I am trying to cope with life and that I am getting } \\
\text { there. It really means I go for quality. I know what I am doing and I know what I } \\
\text { need. }\end{array}$ \\
\hline $\begin{array}{l}\text { Behoefte aan egobesker- } \\
\text { ming }\end{array}$ & $\begin{array}{l}\text {... sometimes you can't be sure of yourself, you need some other people's advice. } \\
\text { Other people might have experience of some of the electrical household appli- } \\
\text { ances that I want to buy of which I don't have any experience. If I ask my cousin, I } \\
\text { know maybe she went across something and somebody told her this brand name } \\
\text { is okay, so she can maybe advise me to take this brand name because of this and } \\
\text { this. }\end{array}$ \\
\hline Behoefte aan selfgelding & $\begin{array}{l}\text {... we like to be like those high societies ... we need to be more admirable by other } \\
\text { people. } \\
\text { With us blacks - we like to be "on top". }\end{array}$ \\
\hline Behoefte aan affiliasie & $\begin{array}{l}\text { Lilly (my friend) is after me with some of the things, she wants to know me better, } \\
\text { she wants to know what kind of things I like. This is true not for big electrical } \\
\text { household appliances only. Since there are people that I admire, I would like to } \\
\text { make friends with them, to get to know them better, and to know what lifestyle they } \\
\text { like. }\end{array}$ \\
\hline Behoefte aan modellering & $\begin{array}{l}\text { When I go, maybe go to visit one of my friends, and I see something that maybe I } \\
\text { don't have, I compare that: "Oh, I like that; one day I might get something like } \\
\text { that"... not the same because I appreciate what she has got. } \\
\text {... through them I can learn a lot, I can see myself doing a lot of things, I can try } \\
\text { myself to get there. }\end{array}$ \\
\hline
\end{tabular}

deur die instandhouding van verhoudinge met belangrike ander (soos vriendinne en verwysingsgroepander) beïnvloed, aangesien die subjekte die aankoop van elektriese huishoudelike toerusting wat soortgelyk is aan dié van persone wat hulle admireer, in die vooruitsig stel.

Behoefte aan modellering Die behoefte aan modellering verwys na nabootsing van die gedrag van persone met wie die verbruiker identifiseer. Dit dui ook op die navolging van verwysingsgroepnorme. Die verbruikersgedrag van hierdie persone dien as 'n verwysingspunt waaraan die subjekte hulle eie aankoopgedrag kan meet (McGuire in Hawkins et al, 1992:303). In hierdie studie koop en gebruik die subjekte soortgelyke groot elektriese huishoudelike toerusting as die persone met wie hulle wil assosieer.

Behoefte aan versterking Volgens Loudon en Della Bitta (1993:328) is verbruikers dikwels gemotiveer om op 'n bepaalde wyse op te tree omdat dié gedrag voorheen vergoeding of 'n positiewe reaksie tot gevolg gehad het. Dit is moontlik, vanweë die verwagte lewensduur en die hoë koste verbonde aan die koop van groot elektriese huishoudelike toerusting, dat die behoefte aan versterking nie uit die subjekte se reaksies afgelei kon word nie.

Twee opkomende verbruikers se gebruik van ander persone se eienaarskap van groot elektriese huishoudelike toerusting as ' $n$ simbool om stereotipiese afleidings/veralgemenings oor ander te maak

Die reaksie van subjekte word in Tabel 2 met die teorie in verband gebring.

Betekenisvolle ander en verwysingsgroep-ander In hierdie studie speel die twee opkomende verbruikers se vriendinne en familie, as betekenisvolle ander, 'n rol in hulle keuse van groot elektriese huishoudelike toerusting. Volgens die simboliese interaksionisme verteenwoordig verwysingsgroepe dié groepe waaraan die individu behoort of aspireer om aan te behoort (Charon, 1979:26). Die respons van die twee subjekte dui daarop dat hulle die lede van die hoër sosiale klasse, as 'n kategorie, admireer. Die subjekte leer die perspektiewe van die aspirasieverwysingsgroep deur simboliese interaksie aan en dit rig 
TABEL 2: $\quad$ STELLINGS MET BETREKKING TOT EIENAARSKAP VAN GROOT ELEKTRIESE HUISHOUDELIKE TOERUSTING AS 'N SIMBOOL OM STEREOTIPIESE AFLEIDINGS/ VERALGEMENINGS OOR ANDER TE MAAK

\begin{tabular}{|c|c|}
\hline Verbruikerstereotiperingsproses & Subjekte se stellings \\
\hline $\begin{array}{l}\text { Interaksie met ander: } \\
\text { Sosiale kategorieë }\end{array}$ & $\begin{array}{l}\text { I admire my cousin and the people of the higher socioeco- } \\
\text { nomic positions. Through them I can learn a lot, I can see my- } \\
\text { self doing a lot of things, I can try myself to get there. } \\
\text { Other people might have experience of some of the electrical } \\
\text { household appliances that I want to buy of which I don't have } \\
\text { any experience. If I ask my cousin, I know maybe she went } \\
\text { across something and somebody told her this brand name is } \\
\text { okay, so she can maybe advise me to take this brand name } \\
\text { because of this and this. }\end{array}$ \\
\hline $\begin{array}{l}\text { Stereotipiese afleidings: } \\
\text { Assosiasie van eienaarskap met lede van } \\
\text { bepaalde sosiale kategorieë }\end{array}$ & $\begin{array}{l}\text { The people of Hospital View prefer a separate stove (hob), } \\
\text { double-door oven, and "this one what do you call this"... (Sy } \\
\text { wys na die dak.) Die navorser pols: "The cookerhood" en die } \\
\text { subjek beaam dit. They will like glass because it is a new } \\
\text { thing, it is a modern thing, they go on with a new life. (Sy ver- } \\
\text { wys na 'n glaskeramiekstoofblad.) } \\
\text { They will prefer the combination fridge-freezer because it is a } \\
\text { modern one and it is beautiful. } \\
\text { They will buy washing machines and tumble driers and they } \\
\text { must make a space in the cabinet for it. }\end{array}$ \\
\hline $\begin{array}{l}\text { Simboliese betekenisse wat toerusting oor die } \\
\text { eienaars kommunikeer }\end{array}$ & $\begin{array}{l}\text {... it gives you an indication of her work and her earnings. } \\
\text { She is an advanced woman, she likes beautiful things, she } \\
\text { likes modern things and she buys once, good things, strong } \\
\text { things. She likes luxury things ... }\end{array}$ \\
\hline
\end{tabular}

hulle aankoopgedrag om soortgelyke groot elektriese huishoudelike toerusting as die aspirasieverwysingsgroep te koop.

\section{Stereotipiese afleidings Volgens Fiske en} Taylor (1991:119) is stereotipes bepaalde rolskematas wat mense se verwagtinge oor ander lede van 'n bepaalde sosiale kategorie organiseer. Die twee subjekte vorm stereotipes oor die lede van die hoër sosioekonomiese klasse op grond van visueel opvallende kenmerke soos hulle sosiale status en die visueel opvallende elektriese huishoudelike toerusting wat hulle sosiale status weerspieël. Die subjekte verkeer dus onder die indruk dat die lede van die hoër sosioekonomiese klasse bepaalde elektriese huishoudelike toerusting verkies.

Simboliese betekenisse oor eienaars Lennon en Davis (1989) is dit eens dat die visuele kategoriseringsproses ' $n$ waarnemer se vermoë fasiliteer om die gedragskenmerke en persoonlikheid van individue wat met die stereotipe geassosieer word te ken of te voorspel. Die subjekte is onder die indruk dat groot elektriese huishoudelike toerusting simboliese betekenisse oor die eienaars daarvan kommunikeer, naamlik hulle beroep, inkomstepeil, dat hulle van mooi, moderne, duur, tegnologies gevorderde groot elektriese huishoudelike toerusting met 'n verwagte lang lewensduur hou asook dat hulle moderne en ingeligte verbruikers is wat met verandering tred hou.

Twee opkomende verbruikers se keuse van groot elektriese huishoudelike toerusting as ' $n$ simbool om betekenisse aan ander met wie hulle in interaksie verkeer te kommunikeer

In Tabel 3 word die simboliese betekenisse (direkte response) wat die subjekte deur hulle eienaarskap van groot elektriese huishoudelike toerusting kommunikeer met die teorie (tweedeordekonsepte) in verband gebring.

Volgens die studiebevindinge kommunikeer die subjekte se groot elektriese huishoudelike toerusting simboliese betekenisse aan en oor hulle. Die toerusting moet behalwe funksionele werkverrigting, ook aan ander met wie die subjekte in interaksie verkeer, toon dat die hoë lewenstyl wat nagestreef word binne bereik is. Vir hierdie subjekte weerspieël die groot elektriese huishoudelike toerusting hulle inkomste, beroep, werkplek, strewe na kwaliteit asook dat hulle moderne verbruikers is wat nie vir verandering bang is nie. 
TABEL 3: $\quad$ STELLINGS WAT DUI OP DIE KEUSE VAN GROOT ELEKTRIESE HUISHOUDELIKE TOERUSTING AS 'N SIMBOOL OM BETEKENISSE AAN ANDER MET WIE HULLE IN INTERAKSIE VERKEER TE KOMMUNIKEER

\begin{tabular}{|l|l|}
\hline Betekenisse & Subjekte se stellings \\
\hline $\begin{array}{l}\text { Weerspieëling van lewenstyl, } \\
\text { salaris, werkplek }\end{array}$ & $\begin{array}{l}\text {.. the woman (lady) will say that she won't go for small things, she seems to be a } \\
\text { woman of image, she is a high-class woman. She works for a big company, she } \\
\text { earns a lot of money ... When the woman looks at her appliances she will see it } \\
\text { as a distance to get there. She will say: "I will never own that, it is too much, it is } \\
\text { too expensive." } \\
\text { Strewe na kwaliteit } \\
\text { Moderne verbruikers }\end{array}$ \\
$\begin{array}{l}\text { It really means I go for quality, I know what I am doing and I know what I need. } \\
\text { and like the people of today ... I like new things and changes. }\end{array}$ \\
\hline
\end{tabular}

\section{GEVOLGTREKKINGS EN AANBEVELINGS}

Volgens die simboliese interaksionisme betree die self (verbruiker) ' $n$ situasie met ' $n$ bepaalde self, verwagtinge, motiewe, opinies en so meer (Van Rensburg \& De Klerk, 1984). Aspekte wat die verbruiker in die situasie inbring, kan aanleiding gee tot die vorming van rolskemata oor die verbruiker se aspirasieverwysingsgroepe. Hierdie rolskemata (stereotipes) dikteer (uit die verbruiker se oogpunt) watter elektriese huishoudelike toerusting die verwysingsgroepe waarskynlik besit of behoort te besit en watter simboliese betekenisse hulle met behulp van die toerusting kommunikeer.

Volgens ' $n$ kognitiewe benadering maak die verbruiker van bepaalde kognitiewe strukture soos stereotipering gebruik om afleidings te maak oor ander persone wat bepaalde elektriese huishoudelike toerusting besit. Die sosiale motiewe van die verbruiker, die invloed van die verwysingsgroepe, en die simboliese betekenisse wat deur die elektriese huishoudelike toerusting van die verwysingsgroepe (uit die verbruiker se oogpunt) gekommunikeer word, rig die verbruiker se gedrag teenoor die verwysingsgroepe. Al hierdie faktore speel ' $n$ rol in hoe die verbruiker ' $n$ situasie ervaar en interpreteer. Hierdie faktore bepaal ook die boodskappe wat die elektriese huishoudelike toerusting wat in persoonlike besit is, kommunikeer.

In hierdie studie is gevind dat die twee opkomende verbruikers wel simboliese boodskappe deur hulle eienaarskap van elektriese huishoudelike toerusting kommunikeer. Hieruit volg dat elektriese huishoudelike toerusting nie net ter wille van funksionele eienskappe gekoop word nie, maar dat dit ook aangewend word om 'n boodskap oor te dra.

Die keuse van groot elektriese huishoudelike toerusting word deur ' $n$ aantal faktore beïnvloed. Sommige faktore is meer voor die hand liggend, byvoorbeeld prys, duursaamheid en werkverrigting. Interne, persoonlike faktore soos onderliggende motiewe en ver- bruikerstereotipering speel egter ' $n$ bydraende rol in die keuse van die toerusting. Waar die eersgenoemde faktore die funksionele en finansiële risiko verminder, bestry die laasgenoemde faktore psigologiese en sosiale risikopersepsies.

Die bevindinge van die studie kan van waarde wees vir vervaardigers, bemarkingsboodskappe en verbruikersopleidingsprogramme:

Vervaardigers van groot elektriese huishoudelike toerusting Benewens klem op die bekostigbaarheid, duursaamheid en werkverrigting van elektriese huishoudelike toerusting, behoort die rol van aspirasiefaktore, die verbruiker se onderliggende motiewe en verbruikerstereotipering in ag geneem te word wanneer veral die distribusie van toerusting en die keuse van afsetgebiede beplan word. Die aanname dat verbruikers in die laer sosioekonomiese groepe slegs in goedkoper, minder gesofistikeerde toerusting belangstel of op konkrete aspekte soos prys ingestel is, ontneem verbruikers die geleentheid om behoeftebevredigende alternatiewe te kies.

\section{Die kommunikasie van bemarkingsboodskappe} aan verbruikers Hoewel opvallende faktore soos prys en ontwerp belangrik is om mededingende produkte in die mark van mekaar te onderskei, kan die aard van die boodskap en die konteks waarin dit aangebied word, bydra om verbruikers "gerus te stel" omtrent die aanvaarbaarheid van bepaalde toerusting in bepaalde situasies. Toerusting wat in ' $n$ bepaalde situasie uitgebeeld word waar die omgewing en die eienaars duidelik onderskei kan word, kan dus 'n groter impak hê as toerusting wat in isolasie vertoon word.

\section{Verbruikersopleidingsprogramme}

Die behoeftes van verbruikers op alle vlakke moet in aanmerking geneem word tydens raadgewing. Begrip vir die onderliggende motiewe van verbruikers en die oordrag van inligting binne so ' $n$ behoefteraamwerk bied ' $n$ beter kans om verbruikers te bereik en verbruikerstevredenheid te bewerkstellig. 


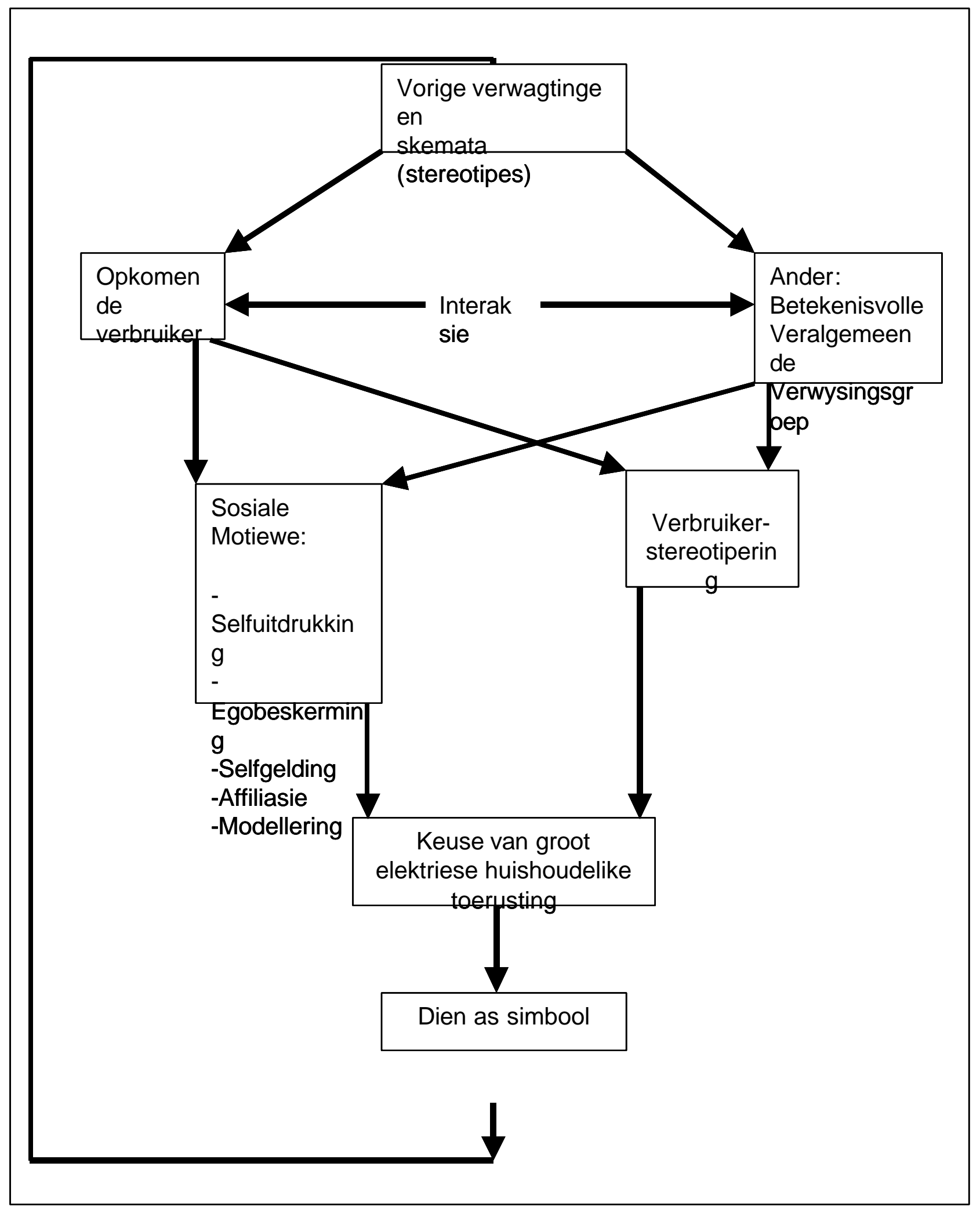

FIGUUR 1: SKEMATIESE VOORSTELLING VAN DIE KONSEPTUELE RAAMWERK VIR VERDERE STUDIE 
Die volgende konseptuele raamwerk, wat op die perspektief van die simboliese interaksionisme en ' $n$ kognitiewe benadering berus, kan as vertrekpunt dien vir verdere verbruikersnavorsing oor die rol van onderliggende sosiale motiewe en verbruikerstereotipering in die keuse van groot elektriese huishoudelike toerusting (Figuur 1). Volgens hierdie raamwerk verkeer die opkomende verbruiker in interaksie met betekenisvolle ander en verwysingsgroep-ander. Die opkomende verbruiker en die "ander" betree 'n bepaalde situasie met 'n bepaalde self, verwagtinge, motiewe, opinies, vorige ondervinding, skemas ensomeer.

Sosiale motiewe is aangeleerde motiewe wat vanweë interaksie met ander ontstaan (Hawkins et al, 1992:298). Opkomende verbruikers en hulle betekenisvolle ander het hulle eie sosiale motiewe wat weerspieël word in behoefte aan selfuitdrukking, egobeskerming, selfgelding, affiliasie en modellering. Aangesien die bevindinge van die studie toon dat opkomende verbruikers se behoefte aan versterking nie 'n betekenisvolle rol by die keuse van groot elektriese huishoudelike toerusting speel nie, is dit nie in die konseptuele raamwerk opgeneem nie.

Verbruikerstereotipering vind tydens interaksie met ander plaas (Hyatt, 1992:299-303). Opkomende verbruikers en hierdie ander persone pas verbruikerstereotipering vanuit hulle eie konteks of oogpunt toe.

Sosiale motiewe en verbruikerstereotipering word deur bestaande stereotipes en verwagtinge oor spesifieke sosiale kategorieë beïnvloed. Verbruikerstereotipering en die sosiale motiewe van opkomende verbruikers speel ' $n$ rol in hulle keuse van groot elektriese huishoudelike toerusting.

Opkomende verbruikers se keuse en gebruik van groot elektriese huishoudelike toerusting dien as 'n simbool om ' $n$ bepaalde sosiale boodskap(pe) aan ander te kommunikeer. Hierdie verbruikers gebruik "ander" se keuse en eienaarskap van groot elektriese huishoudelike toerusting as ' $n$ simbool om stereotipiese afleidings oor die eienaars te maak. Die "simboliese gebruik" van elektriese huishoudelike toerusting vorm deel van 'n terugvoerlyn wat die opkomende verbruiker se oorspronklike stereotipes en verwagtinge kan beïnvloed en verander.

\section{LITERATUURVERWYSINGS}

BOGDAN, RC \& TAYLOR, SJ (1975): Introduction to qualitative research methods: a phenomenological approach to the social sciences. New York. Wiley.

BURNS, LD \& LENNON, SJ (1993): Social perception: methods for measuring our perception of others. International Textile and Apparel Association Special Publication 5:153-159.

CHARON JM (1979): Symbolic interactionism - an introduction, an interpretation, an integration. 2nd ed. Englewood

Cliffs, NJ. Prentice-Hall. navorsingsmetodes vir die bestudering van dogters se kledinggedrag. Tydskr Dieetkd Huishkd 21(2):88-94.

ENGEL, JF, BLACKWELL, RD \& MINIARD, PW (1995) Consumer behaviour. 8th ed. London. Dryden.

ERASMUS, AC (1997): Black consumers' approach to the acquisition of electrical household appliances. J Dietet Home Econ 25(2):100-113.
FERBER, R (1974): Handbook of marketing research. New York. McGraw-Hill.

FISKE, ST \& TAYLOR, SE (1984): Social cognition. Lon-

don. Addison-Wesley, SE (1991): Social cognition. 2nd ed. New York. McGraw-Hill.

GORDON, W \& LANGMAID, R (1988): Qualitative market research. Aldershot. Gower.

HAIRE, M (1950): Projective techniques in marketing research. J Mark Res 14(5):649-656.

HAMILTON, DL (1979): A cognitive-attributional analysis of stereotyping. Perc and Mot Skills 29:191-194.

HAWKINS, DI, BEST, RJ \& CONEY, KA (1992): Consumer behavior. Implications for marketing strategy. 5th ed. Boston. Irwin.

HYATT, EM (1992): Consumer stereotyping: the cognitive bases of the social symbolism of products, in SHERRY, JF \& STERNTHAL, B. (eds). Diversity in consumer behavior. Advances in Consumer Research 19. Association for Con-

KAISER, SB (1983-1984): Toward a contextual social psychology of clothing: a synthesis of symbolic interactionist and cognitive theoretical perspectives. Cloth Text Res $\mathrm{J} 2$ (1):1-9.

KÁISER, SB (1990): The social psychology of clothing. Symbolic appearances in context. 2nd ed. New York. MacMillan.

LENNON, SJ \& DAVIS, LL (1989): Clothing and human behaviour from a social cognitive framework. Part I: Theoretical perspectives. Cloth Text Res J 7(4):41-48.

LOUDON, DL \& DELLA BITTA, AJ (1993): Consumer behaviour. Concepts and application. 4th ed. New York. McGraw-Hill.

MARKINOR OMNI PANEL SURVEY (1997): Eskom. March. MORGAN, CT \& KING, RA (1975): Introduction to psychology. 5th ed. Tokyo. McGraw-Hill.

MOUTON, J (1983): Kwantitatiewe en kwalitatiewe metodologieë in die geesteswetenskappe. S Afr Tydskr Sosiol 14(4):124-131.

MOUTON, J \& MARAIS, HC (1990): Basiese begrippe: metodologie van die geesteswetenskappe. Pretoria. RGN

NAGASAWA, RH, HUTTON, SS \& KAISER, SB (1991): A paradigm for the study of the social meaning of clothes: complementary of social psychological themes. Cloth Text Res J:10(1):53-62.

SCHURINK, EM (1988): Die metodologie van ongestruktureerde onderhoudvoering, in FERREIRA, GP et al. (eds). Inleiding tot kwalitatiewe metodes. Module 3 . Pretoria. RGN.

VAN RENSBURG, HCJ \& DE KLERK, GW (1984): Simboliese interaksionisme: 'n mikrososiologiese oriëntasie. S Afr Tydskr Sosiol 15(1):46-55. 